\title{
Why teach or learn about the Holocaust? Teaching aims and student knowledge in English secondary schools
}

\author{
Alice Pettigrew
}

\begin{abstract}
This paper explores relationships between teaching aims and student knowledge and understanding of the Holocaust in discussion of selected findings from two large-scale empirical studies conducted in English secondary schools. It draws on the work of educational theorists Gert Biesta and Michael Young in order to extend and expand upon the dominant, dichotomising discourse of "historical versus non-historical" approaches within which much existing Holocaust education literature has previously been framed. Following Young, the paper asks: What forms of knowledge of the Holocaust are most "powerful" in terms of facilitating student understanding? And further: Which teaching aims are best suited to ensuring all students have access to these?
\end{abstract}

Keywords: Holocaust; secondary education; teaching aims; student understanding; powerful knowledge; curriculum

\section{Authors' correspondence}

Dr. Alice Pettigrew

Senior Research Associate

UCL Centre for Holocaust Education.

20 Bedford Way

London, WC1H 0AL

a.pettigrew@ucl.ac.uk

\section{Notes on author}

Alice is a Senior Research Associate in the UCL Centre for Holocaust Education. She is the lead author of Teaching the Holocaust in English Secondary Schools: An Empirical Study of National Trends, Perspectives and Practice and a co-author of What do students know and understand about the Holocaust? Evidence from English Secondary 
Schools. Alice also researches processes of identity formation, the intersections of "ethnicity", "race" and "nation", as well as multicultural and antiracist pedagogy.

It's an interesting one that you should ask that, because it's something ... you kind of just assume to some extent that [students] should know about the Holocaust, rather than even think about whether there's any reason why they should know about it. ${ }^{1}$

Ella: I think people should know about it, like the basics of it. I just thought ... I just thought maybe it's the actual event isn't as important as the concept of it is.

Interviewer: What do you mean by 'the concept of it'?

John: Like what Ella was saying, you should know it - you don't come out of it happy - you know it's wrong, and people should know it's wrong. But I feel more that that's important rather than knowing the details of the actual event. ${ }^{2}$

\section{Introduction}

The Holocaust has been included as compulsory content to be taught in all of England's state maintained secondary schools since the introduction of the country's first national curriculum in 1991. In the years since then, five different Prime Ministers and thirteen Secretaries of State for Education have overseen a number of significant curricular revisions and restructures but in its present iteration, the symbolic significance of the Holocaust has never been more profound. ${ }^{3}$ In the current curriculum, the Holocaust is listed alone as the only named content that must be included within a unit of study entitled, "Challenges for Britain, Europe and the wider world 1901 to the present day". This should be taught within history lessons before students reach the end of Key Stage 3 (typically by the age of 14). ${ }^{5}$ By point of comparison, other key twentieth-century 
events including both the First and Second World Wars and the end of the British Empire are listed only as non-statutory content that teachers "could" choose to include. 6

However, and in keeping with all four previous curricular framings of the Holocaust in England, the 2014 programme of study does not offer teachers - or their students - any explanation as to why the Holocaust is positioned with such singular importance. Nor does it offer any further guidance as to the specific form or content of knowledge and understanding that it is envisaged such teaching will enable or encourage students to acquire. Indeed, as Pearce and Russell have both argued, throughout its entire twenty-five year history, the statutory provision for teaching and learning about the Holocaust in England's schools has been marked - and in some interpretations marred - by the absence of any clear discussion or deliberation at a policy level of exactly what should be taught about under the rubric of "the Holocaust" or why. ${ }^{7}$ In place of such discussion, the educational import of the Holocaust has been presented as though self-evident and uncontentious: as the history teacher whose words opened this paper remarks, "you kind of just assume [. . . that [students] should know about the Holocaust, rather than even think about whether there's any reason why".

But, as the discussion that follows will argue, a teacher's rationale or motivation for teaching about the Holocaust - whether made explicit or only ever implicitly held can have profound impact upon their classroom practice and, as a consequence, upon the meaning - or otherwise - that their students may be able to derive. Without an answer to the question, "Why teach about the Holocaust?" on what basis should a teacher determine what content to include? Is it sufficient for young people to simply be aware of - or "know about" - the Holocaust as Ella and John, ${ }^{8}$ the two students whose discussion also frames the opening of this paper, appear to suggest: to know that it happened and moreover, in John's words, "to know it's wrong"? If this is not 
sufficient, what further forms of understanding or interpretation are required? How important is accurate historical knowledge, "the details of the actual event"? And, following Ella, what relation does such knowledge have to "the concept of the Holocaust", that is, the forms of abstracted or generalised meaning that some commentators consider it both possible and necessary to derive?

This paper will critically consider these and other questions by synthesizing selected findings drawn from two recent empirical studies conducted in English secondary schools. The first study, published in full in 2009, examined teachers' perspectives on teaching about the Holocaust and their accounts of classroom practice while the second, published in 2016, investigated student knowledge and understanding of this history. ${ }^{9}$ At the point of publication, both were internationally unprecedented in terms of their extensive scope and scale. The teacher study was built around 2,108 teachers' responses to a detailed, 54-question survey instrument and semi-structured interviews with 68 teachers from 24 different schools. The student study offered analysis of 7,952 students' responses to a 91-question survey and thematic focus group interviews with a further 244 students in 17 schools. Full details of the methods of data collection and analysis used within each study are included within the research reports, Teaching About the Holocaust in English Secondary Schools, and What do Students Know and Understand about the Holocaust? Together, the two studies offer an invaluable opportunity to critically consider teachers' answers to the question, "Why teach about the Holocaust?" and their potential salience for student knowledge and understanding at secondary school.

In a departure from much existing literature within this field, the current paper looks beyond the study of the Holocaust in its analysis of teaching aims and student knowledge by drawing its primary theoretical insight from recent discussion within the 
fields of the philosophy of education and educational sociology. This theoretical framing returns our attention to fundamental questions about the aims and purpose of education more broadly and to the relative importance placed upon different forms of knowledge within competing articulations of these. In doing so, the paper proposes that, as it is currently constructed through policy frameworks and most commonly enacted in English secondary schools, teaching and learning about the Holocaust primarily functions within a domain characterised by philosopher Gert Biesta as educational "socialisation" while important opportunities for educational "subjectification"- that is, educational processes which encourage autonomous thought and action and which confer individual agency - are regularly lost or denied. ${ }^{10}$ The resonance and relevance of Michael Young and others' recent argument regarding student access to "powerful knowledge" is also examined, both with reference to "the concept" and "the content" of the Holocaust as articulated by Ella and John above. ${ }^{11}$

\section{Why teach about the Holocaust? Perspectives from existing commentary and empirical research.}

The importance of clear educational rationales for approaching the Holocaust in classrooms has long been recognised by those pedagogical commentators and empirical researchers who have already contributed significantly to our understanding of teaching and learning in this field. For example, in the opening lines of the United States Holocaust Memorial Museum's 1993 pamphlet, Guidelines for Teaching About the Holocaust, the authors immediately invite their readers to critically consider, "Why Teach Holocaust History?"12 A very similar question frames the first in a series of recommendations for teachers produced by the International Holocaust Remembrance Alliance (IHRA), an intergovernmental association of 31 member states who share a commitment to supporting Holocaust remembrance, education and research. ${ }^{13}$ 
Furthermore, an extensive, multilingual, review conducted on behalf of the IHRA's educational working group records that teachers' aims were the focus of several recent empirical research studies across the globe ${ }^{14}$ while in England in 2001, a whole special edition of the professional journal Teaching History was dedicated to a discussion of competing rationales for the inclusion of the Holocaust within the national curriculum. ${ }^{15}$

Each of these contributions share and emphasise a recognition both that there are multiple possible answers to the question, "Why teach about the Holocaust?" and, moreover, that best practice in classrooms depends upon clear consideration and articulation of these. Totten, Feinberg and Ferenkes, for example, insist that it is "essential to establish a solid set of rationales" as the basis for guiding content selection and choosing between different pedagogical strategies. ${ }^{16}$ Citing Holocaust survivor and historian Henry Friedlander, they warn that, without this focus, even the most motivated of teachers risk "destroying the subject matter through dilettantism". ${ }^{17}$ But beyond this common starting premise, there are important divergences within this body of literature too. For where Totten, Feinberg and Ferenkes go on to provide an extensive, but by no means exhaustive list of illustrative rationales - including, for example: "to study human behaviour"; "to teach students why, how, what, when, and where the Holocaust took place"; "to develop in students an awareness of the value of pluralism and diversity in a pluralistic society"; and, "to examine the nature, purpose and structure of governments" - they do not then attempt any form of critical judgement as to the relative merit, strength or limitation of each of these. Elsewhere within this body of literature, however - and certainly within the context of the United Kingdom - it is far more common for individual commentators to implicitly - and in many cases explicitly - advocate in favour of particular, often subject-specific, teaching rationales. 
Perhaps one of the clearest expressions of this is to be found in Nicholas Kinloch's 1998 Teaching History article, “Learning about the Holocaust: moral or historical question?" Here Kinloch argued that it was mistaken for history teachers to approach their work with consideration either to the morality of their students, or to wider societal concerns. Instead he advocated clearly, "we have to start and end with what happened and why, with the Shoah as history". ${ }^{18}$ Kinloch's article, and others that were written in direct response, are characteristic of the dominant discursive framework within which most British academic consideration of the aims appropriate to teaching about the Holocaust has taken place. Here various contributors have reflected upon whether it is appropriate, and/or of most educational value, for teachers to begin and end with the historical study of the Holocaust or whether it is equally important for specific forms of moral development, spiritual reflection and/or citizenship education to be emphasised. ${ }^{19}$ While some authors would recognise that it might be neither possible, nor entirely desirable to firmly insist upon the clear separation and disentanglement of individually isolatable teaching aims,${ }^{20}$ taken as a whole, the overwhelming impression across this work is of a field divided between those who prioritise ostensibly disciplinary historical approaches and those who defend or promote "other" -by default, typically positioned as "non historical" - in some analyses, "metahistorical"21 _"moral", "civic", "social', "emotional" and/or in some cases "spiritual" teaching aims.

This in turn reflects continuing wider debate regarding the status, form and content of school-based disciplinary history in England and the rest of the UK. ${ }^{22}$ Although history is the only curriculum area within which the Holocaust is stipulated as required content, recent research with both students and teachers indicates clearly that the topic is regularly approached and encountered in a wide variety of subject areas including - but not limited to - religious education, English, citizenship, personal, 
social and health education (PSHE) and drama. ${ }^{23}$ Even the staunchest advocates for a disciplinary historical approach would likely concede that alternative framings may be appropriate and beneficial in these other fields. ${ }^{24}$ Of more concern to many history educators, however, is the apprehension that even within history classrooms the Holocaust is regularly identified for its cross-curricular potential and/or commonly approached by teachers with reference to trans-disciplinary teaching aims. From this perspective, in some commentators' accounts, the Holocaust has become emblematic of a more widespread and more pernicious problem whereby school history has been appropriated to serve "present-oriented" and "instrumental" rather than "intrinsic" educational goals. ${ }^{25}$

This is a tension that was only exacerbated further by the educational agendas of the Labour government who came to power in 1997. In many respects, both the Blair and Brown governments advanced what Kate Hawkey and others have characterised as an "accessibility agenda" 26 promoting generic skills and competencies and prioritising "relevance" - in reference both to students' existing, every day experience and to their presumed prospective employability - at the expense of secure knowledge content and strong disciplinary subject boundaries. Of most significance to our current discussion were two specific policy decisions. The first was the establishment in 2000 of an annual Holocaust Memorial Day which was politically framed in a manner that made very explicit links between understandings derived from the Holocaust and twenty-first century concerns such as "managing diversity", "community cohesion" and "multicultural citizenship". ${ }^{27}$ The second, in 2002, was the introduction and active promotion of statutory "Education for citizenship" within the national curriculum with accompanying guidance that this should have strong curricular links with disciplinary history. ${ }^{28}$ 
Concerns over the instrumentalisation of the study of the past are not without substance or salience and will be returned to throughout the remainder of this paper. However, I would argue the strong defences that have been mounted against the (mis)appropriation of disciplinary history in general and of teaching about the Holocaust in particular have contributed to a widespread reproduction of a somewhat misleading, reductionist, and in many ways unhelpful dichotomous polarisation between "historical" and - in the most commonly used of shorthands - "moral" approaches that could be taken in schools. I indicate a "commonly used shorthand" because, as already noted, the aims most regularly presented as being held in tension against historical perspectives are not only those described as "moral" but also those variously positioned as "social", "civic", "emotional"/"affective" and/or "spiritual". Yet considering the prominence given to such labels as negative exemplars in the arguments of Kinloch, Russell, Salmons, Pearce and many others, it is striking that scant attention is ever paid as to precisely what constitutes a "moral" or "social" educational aim. ${ }^{29}$ Instead, these and other terms are most regularly employed without discussion as though they can be used unproblematically for the clear categorisation and classification of competing educational rationales. In practice, however, each term belies its own internally contested field. ${ }^{30}$

It is especially unclear what exactly is being designated where the label "social education" is employed. The term appears in tandem with "moral education" sufficiently frequently to imply that the commentators who use both terms together recognise a relationship but also a distinction between the two. And yet, overwhelmingly, the same authors go on to use the two terms as though they are entirely interchangeable suggesting that the only analytic point of consequence is their shared distance and difference from distinctly "historical" disciplinary aims. ${ }^{31}$ 
The first cost of such conceptual imprecision is that it forecloses important critical reflection upon the relative merits of competing approaches to learning about the Holocaust from within either an overarching "moral education", or "social" - here interpreted as "citizenship education" - frame. As a consequence, these areas have not always been given the serious analytic attention they arguably deserve.

A second concern is that, by framing most related discussion through a dichotomising discourse of "historical" versus "non-historical" - or "other-thanhistorical" - teaching aims, there is a danger attention is misdirected away from the most pertinent and perceptive diagnoses of the obstacles most likely to prevent meaningful educational encounter with the Holocaust in schools. For example, commentators such as Andy Pearce and Paul Salmons in the United Kingdom and Steve Feinberg in the United States, have each argued powerfully against what they characterise as widely popular but problematic "lessons from" approaches to this past. These, they argue, can serve to obscure or distort student understanding by imposing or in Lawrence Langer's useful phrase, “preempting” - restrictive, often redemptive, over-simplistic and/or universalised meaning of and/or from this history. ${ }^{32}$ For example, in a 2003 article, Salmons interprets Feinberg to argue of,

\footnotetext{
the need for educators to separate out the history of the Holocaust from the lessons of that history. He [Feinberg] warns against the oversimplification of a complex historical narrative to convey universal moral lessons - the difference, he has said, between "teaching and preaching". 33
}

However, in framing this discussion under a juxtaposition between "moral lessons or historical understanding", as Salmons does, ${ }^{34}$ the distinction between "lessons" on the one hand and "understanding" on the other gets mapped onto, and risks being reduced to, the familiar "historical versus non-historical" divide. But our primary cause for concern here as educators should be the "preempting" or imposition of oversimplified 
and/or universalised meanings - not the moral educational approaches to which such processes appear discursively aligned. There is no intrinsic reason why "moral" - or for that matter "civic" or "social" educational approaches demand, or should necessarily entail, any such distortion of the past, for there is more to moral and social education than moralising and social-engineering. Indeed, as Salmons himself highlights elsewhere within the same article,

This does not mean, however, that learning the history of the Holocaust and drawing moral [and we could equally argue, "civic", "sociological", "political" and/or "philosophical"] lessons for today are mutually exclusive. History is the story of human experience and behaviour and, in studying the history in depth, we may yet learn more about ourselves. ${ }^{35}$

The distinction is in fact rather one of precedence and prioritisation and the danger of distortion lies where, "the prime goal of the educator is to teach the lessons" - and I would add, "lessons" that have themselves been predetermined - "rather than the history" ${ }^{36}$ I would insist it is specifically with regard to this "pre-empting" or predetermination that the "preaching rather than teaching" analogy most accurately holds. This, however, is arguably foremost an issue of bad pedagogy - what Haydn has characterised as, "history with the thinking taken out" 37 - rather than of the relative value or suitability of historical over other forms of educational aim. Contra the straw man employed within the most strident of disciplinary historical defences, "thinking" is a constitutive component of both good moral education and good citizenship education in any field. ${ }^{38}$ Yet the question of what "good" - rather than reductionist, or pre-empted - moral and/or social approaches to the Holocaust might look like is harder to examine while all such "non-historical" frameworks are characterised foremost as oppositional or contradictory forces rather than potentially complimentary educational aims. 


\section{Beyond the "historical versus moral?", "intrinsic versus instrumental", "teaching versus preaching" divide.}

In the discussion that follows, I will briefly characterise a number of recent important contributions to the fields of the philosophy of education and educational sociology. In doing so, I attempt to move analysis beyond this dichotomising "historical versus nonhistorical" discourse offering an alternative theoretical framework within which to critically consider the empirical findings referenced below.

In recent years there has been something of a resurgence in philosophically oriented literature concerning itself with one of the most elementary of all educational questions: what is education for? Much of this literature has been written in response to what John White has characterised as an "aims-vacuum" in popular and political discussion of education and, relatedly, in policy making fields ${ }^{39}$ In his 2010 text, Good Education in an Age of Measurement, the educational philosopher Gert Biesta, for example, argues that we are currently living within a socio-political and economic climate in which fundamentally important questions regarding what is of value in education have been effectively displaced from popular, political and, to some extent, even academic consciousness, by market-oriented and managerialist discourses which prioritise notions such as "effectiveness", "efficiency" and "accountability". Within such a climate, only the means or technologies of education are ever subject to critique or to scrutiny while the ends or purposes of education are presented as self-evident and thus not open to thoughtful deliberation or debate. ${ }^{40}$ Biesta's central contention is that,

the question of good education - the question of purpose, the question as to what education is for - should actually be a central and ongoing concern within education practice, policy and research. ${ }^{41}$

In this regard it is salient to note how frequently existing discussion of the aims and rationales employed when teaching about the Holocaust - as, for example, in the 
works already cited - is conducted without any concomitant recognition that the purposes of education more broadly are themselves not clearly determined or consensually defined. A short passage that is reproduced in both the United States Holocaust Memorial Museum's and the International Holocaust Remembrance Alliance's respective guidelines for teachers provides striking illustration of this. Within it, a nuanced consideration of multiple potential rationales for teaching about the Holocaust are prefaced by the considerably less circumspect assertion that,

[t]he objective of teaching any subject is to engage the intellectual curiosity of students in order to inspire critical thought and personal growth. ${ }^{42}$

My point here is not to argue against the legitimacy of "engaging intellectual curiosity" or "inspiring critical thought and personal growth" as overarching educational concerns (indeed, both are important dimensions of the potential "subjectifying" function of education that I will later go on to emphasise). Rather, my intention is to identify that this assertion reflects just one of many potential perspectives on the purpose(s) of education which are likely to impact in various ways upon the actions taken and choices made by teachers in classroom contexts. As such it cannot and in Biesta's argument should not - be assumed as guaranteed.

\section{“Qualification", "socialisation" and "subjectification" as distinct but interrelated educational domains}

In order to facilitate ongoing consideration of potential - and potentially competing aims and ends of any form of education, Biesta proposes that we should begin with critical cognisance of three central functions all educational systems perform: "qualification", "socialization" and "subjectification". Here, qualification refers to the role of education in providing individuals with the specific "knowledge, skills and understandings", "dispositions and forms of judgement" which are needed in order for 
them to be able to do particular things in various arenas (such as the labour market, for example, or civil society, or within individual disciplinary fields). Socialization refers to the manners in which education prepares individuals to become part of an existing social, cultural and/or political order through the active or implicit transmission of ostensibly shared traditions, values and norms. In many respects subjectification denotes the opposite of socialisation. It refers to the potential for education to equip young people to stand outside of existing orders, to think independently and act autonomously and perhaps ultimately to be able to challenge and/or transform the status quo. The provisional caveats of the words "potential" and "perhaps" in the preceding sentence are important because, as Biesta himself reflects, "[w]hether all education actually contributes to subjectification is debatable": while "[s]ome would argue that this is not necessarily the case and that the actual influence of education can be confined to qualification and socialization" others - including Biesta himself - insist, "that any education worth its name should always contribute to processes of subjectification" in some form. ${ }^{43}$ The extent to which education about the Holocaust as it is most commonly conceived in English schools is able to contribute specifically to processes of subjectification will be critically considered as part of our discussions below.

At this juncture it is important to clarify that in identifying these three functions, or "domains" of education, Biesta is not suggesting that they can or should then be used as a means of classifying or categorising distinctive teaching aims. Rather, he explains that the three functions always overlap in various ways:

When we engage in qualification, we always also impact on socialization and on subjectification. Similarly, when we engage in socialization, we always do so in relation to particular content - and hence link up with the qualification function and will have an impact on subjectification. And when we engage in education that puts subjectification first, we will usually still do so in relation to particular curricula content and this will always also have a socializing effect. The three 
functions of education can therefore best be represented in the form of a Venn diagram, i.e., as three partly overlapping areas, and the more interesting and important questions are actually about the intersections between the areas rather than the individual areas per se. [. . .]

What is most important here is that we are aware of the different dimensions, of the fact that they require different rationales, and also of the fact that while synergy is possible, there is also potential for conflict between the three. ${ }^{44}$

Shortly, we will consider the possible implication of Biesta's conceptual vocabulary for teaching about the Holocaust in English secondary schools. However, before we do so, it is instructive to outline one further recent contribution to educational theory which has particular resonance and relevance for our analysis here.

\section{"Powerful knowledge" and "knowledge of the powerful"}

Where our discussion up until this point has focussed on questions related to the aims of and rationales offered for education, it is important now to turn our attention to the related positioning of "knowledge", not just within educational theory but also within educational policy, practice and research.

The importance of considering both knowledge content and educational aims in tandem is perhaps expressed most clearly in the work of sociologist Michael Young and others such as Leesa Wheelahan, Rob Moore, Johan Muller and Elizabeth Rata who share his "social realist" epistemological approach. ${ }^{45}$ For Young, the answer to the question, "What are schools for?"46 is relatively clear, although - as he acknowledges not uncontentious, and "takes us directly to the question of knowledge" 47 :

The main purpose of schools can, we argue, be summarized as follows:

It is to enable all students to acquire knowledge that takes them beyond their experience. It is knowledge which many will not have access to at home, among their friends, or in their communities in which they live. ${ }^{48}$ 
From this perspective, the centrally important educational question becomes, "What is it [. . .] important that our young people know?"49 Here it is essential to clarify that Young and his various collaborators ${ }^{50}$ are not advocating a return to archaic conceptions of education as "knowledge of the powerful" in which "learning" is reducible to rote memorisation of the "key facts" considered of most value by the dominant members of any society. On the contrary, Young's whole project can be seen as an attempt to reclaim and reassert the emancipatory potential of certain forms of knowledge which he believes it is incumbent upon teachers, school leaders, curriculum designers and policy makers to make accessible to all students through schools.

Specifically, Young insists upon the curricular importance of what both he and Wheelahan have described as "powerful knowledge", explaining, "knowledge is 'powerful' if it predicts, if it explains, if it enables you to envisage alternatives."

Powerful knowledge refers to what the knowledge can do or what intellectual power it gives to those who have access to it. Powerful knowledge provides more reliable explanations and new ways of thinking about the world and [...]can provide learners with a language for engaging in political, moral, and other kinds of debates..$^{51}$

Following Bernstein, he distinguishes "powerful" forms of knowledge from "common-sense" or "general knowledge" derived from everyday experience. "Powerful knowledge" is not limited to an individual's experience of their own immediate context and can therefore be abstracted and generalised. Like all knowledge it is fallible and ultimately open to contest but represents our best available tools for understanding any given phenomena. In Young and others' analysis, “powerful knowledge" earns its legitimacy and authoritative status through its means of production within specialist communities of practice who share (broadly) agreed rules and 
transparent procedures and a cumulative body of analytic and explanatory conceptual frames.

This analysis has led Young to argue strongly in favour of a subject-based curriculum in opposition both, in practice, to the skills and competencies based curricular approaches promoted by the previous Labour government and, in principle, to curricula oriented to overarching, transdisciplinary aims such as "human flourishing", for example, as articulated in recent publications by John White and Michael Reiss. As a consequence, the notion of "powerful knowledge" has been enthusiastically adopted by many of those keen to preserve of reclaim the disciplinary integrity of school history. $^{52}$

However, while disciplinary boundaries play a crucially important role in Young's analysis and argument, I believe it is important not to reduce the analytic possibilities of the concept of "powerful knowledge" to a defence of traditional subjectled curricula or to get caught in a further rhetorical binary between the prioritisation of subject knowledge versus the prioritisation of broader educational aims. Indeed, Michael Young himself recognises that disciplinary boundaries are not fixed and unchanging although he does insist cross-disciplinary understanding depends upon secure knowledge first produced within a single disciplinary field. Instead, what I take from this necessarily somewhat truncated survey of recent educational theory into the empirical discussion that follows is an understanding that "powerful knowledge" rigorous, corroborated and specialist knowledge content - has a vital role to play if education is to be effective within Biesta's field of "subjectification". Thus, I would argue the critically important questions for researchers - and ultimately for educators are not related to whether or not it is only appropriate to approach the Holocaust in school through "historical" as distinct from "moral" or "social" lenses. Instead, they 
ask: Are some forms of knowledge and understanding of the Holocaust more "powerful" than others? In what respects? And how can our teaching aims and pedagogical practice be best directed if we want to provide students with access to these? To paraphrase both Young and Biesta: What is it important for young people to know about the Holocaust? Do schools provide educational encounters which are distinct from - and potentially able to challenge - students' everyday or common-sense "understanding" of this history? Are existing aims oriented towards developing independent thought and autonomous action, or do they primarily prioritise the inculcation of students into existing traditions, values and norms?

\section{Teaching and Learning About the Holocaust in England's Secondary Schools: Empirical Evidence from the 2009 and 2016 Research}

\section{Teachers' Aims}

The 2009 study provided participating teachers with a number of opportunities to reflect upon their aims and purpose with regard to the teaching the Holocaust in school. Those who completed the online survey were presented with a list of 11 suggestions and asked to identify which three teaching aims they considered most important.

\section{[Please insert 'Figure 1: Variation in teachers' aims by subject background' here].}

Figure 1 charts the responses given from teachers across five different disciplinary areas and illustrates that there was at least some subject-based variation in their prioritisation of teaching aims. For example, Religious Education teachers were proportionately much more likely than others to consider it important to reflect upon theological questions raised by the Holocaust (31.3\% of all RE teachers), or to reflect upon the moral and/or ethical questions raised (44\% of all RE teachers) while history teachers were more likely than others to prioritise: reflection upon political questions about power and its abuse (25.6\% of history teachers); deepening knowledge of the 
second world war and twentieth century history (25.9\% of history teachers); and understanding the actions of people involved in an unprecedented historical event (17.5\% of history teachers). However, more than double that number of history teachers chose to prioritise, "to learn the lessons of the Holocaust and to ensure that a similar human atrocity never happens again" while $67.1 \%$ chose "to develop an understanding of the roots and ramifications of prejudice, racism and stereotyping in any society". Indeed, across all subject backgrounds, the teachers who took part in the 2009 survey were consistently less likely to prioritise distinct disciplinary objectives than these two overarching and subject-traversing aims.

It is important not to infer too much on the basis of a single, forced-choice survey instrument, nor to make too firm or final a distinction between individually isolatable teaching aims. And so, for example, one of the survey respondents who had prioritised, "understanding the roots and ramifications of racism and prejudice"; "exploring the roles and responsibilities of individuals, organisations and governments", and, "exploring the implication of remaining silent" then used the accompanying freetext facility included within the survey to add, "this has to come from detailed historical study", a position entirely in accordance with the argument of Michael Young above.

However, a second question within the same survey presented teachers with a series of statements related to different pedagogical approaches and asked them to indicate the extent to which they agreed or disagreed with each. Strikingly, while $87 \%$ of all teachers who responded to this question (including 93\% of history teachers) agreed with the statement, "I try to give students key facts and information about the Holocaust, providing them with a clear narrative outline" and $88 \%$ (including $83 \%$ of history teachers) agreed, "when teaching about the Holocaust I ask students to consider moral and/or ethical questions", only $21 \%$ of teachers agreed, "when teaching about the 
Holocaust I take a disciplinary approach and focus on historical teaching". Moreover, only $31 \%$ of history teachers agreed.

These issues were also explored in extended small group interviews. Here some participants offered considered reflection upon the pedagogical relationships between disciplinary historical approaches and other forms of moral, civic, or sociological understanding. For others, however, these distinctions appeared considerably less clear. One teacher who taught about the Holocaust in two different curriculum contexts explicitly stated there was "no difference" in her teaching aims whether she delivered the subject in history lessons or within RE. All teachers who took part in interview were also asked to consider why they thought the Holocaust was listed as compulsory content specifically within the history curriculum. Again, while some argued that accurate historical knowledge and a disciplinary framing were fundamentally important to understanding the Holocaust many others found this a particularly difficult question to answer beyond what perhaps seemed to them to be the self-evident explanation that the Holocaust itself had taken place within history.

Yet other teachers described how, for them, the Holocaust stood outside of any specific disciplinary framework, that it was "not like other topics" and demanded its own distinctive pedagogy. One RE teacher, for example, described that, while he had "set patterns" in how he taught every other unit of his syllabus, "the minute I teach about the Holocaust, it really goes out the window". Specifically, he suggested he would not necessarily expect his students to produce any written work when studying the Holocaust and did not consider the unit leant itself to being formally assessed. A colleague from the school's history department agreed:

It's taught differently, definitely ... You can look through [a student's] exercise book and there may not be a great deal there. 
In place of formal written work, many teachers explained they wanted to encourage their students to think and reflect, discuss and debate, or, in place of essay assignments, invited students to produce poetry or other forms of artistic response. In another school one history teacher reflected,

I think [attainment targets are] a nonsense when it comes to the Holocaust. I think that's a paper exercise that I regard as completely meaningless here and I think our progress is much more on a personal level with those individual students ... where you can see them maturing in their thought. And you can't quantify this can you? That's the problem ... I don't think you can quantify it until they've left school, until they're old enough to reflect back on their experiences.

It would be unhelpful and disingenuous to suggest that all valuable learning outcomes must be quantifiable or easy to formally observe but it is nonetheless a significant challenge to the acquisition of "powerful knowledge" if teachers remain unclear as to how to judge their students' progress or the effectiveness of their own pedagogy. For while, as we have already seen, some $87 \%$ of all teachers who answered the relevant survey question agreed that they " $\operatorname{tr}[$ ied] to give students key facts and information about the Holocaust", our most recent study with students in fact suggests that many may lack core knowledge of this history. This is a contention that will be developed further with reference to specific examples below.

\section{“Powerful Knowledge”, “Everyday Knowledge” and Popular Constructions of}

\section{the Holocaust.}

As has already been outlined, Young, Wheelahan and other "social realist" educational theorists emphasise an important distinction between the "powerful knowledge" they believe should be prioritised within classrooms and the "everyday" or "common-sense" forms of general knowledge derived from students' experience outside of school. While, within their own analyses, these writers refer primarily to knowledge acquired within 
the family or local community setting, with reference to the Holocaust, it is also important to account for widely circulating popular constructions of this history. For, as Tim Cole, writing in 1999 suggests, "the Holocaust has emerged - in the Western World - as probably the most oft-represented event of the twentieth century." ${ }^{53} 17$ years later and representations of the Holocaust in art, film and literature continue to proliferate within popular consciousness today. In this regard it is instructive to note that, within the 2016 study, approximately $74 \%$ of Year 7 and $81 \%$ of Year 8 students who had not yet formally learned about the Holocaust were nonetheless familiar with this history. Older students in interview described the Holocaust as "so mainstream" observing, "it's just one of those things people know without even realising they've learned it".

However, as Cole continues, being "well known" does not necessarily equate to being "well understood". On the contrary, drawing on Langer's distinction between "historical" and "rhetorical" planes of consciousness, Cole concludes that,

at the end of the twentieth century it seems to me that there can be no doubt that the myths have become more real than historical reality. ${ }^{54}$

Cole draws particular attention to the enormous significance of the feature film Schindler's List as a source of historical distortion and rhetorical reconstruction of the Holocaust. More recent research suggests that The Boy in the Striped Pyjamas has decisively eclipsed Schindler List in young peoples' popular consciousness, as both the most read book and most watched film cited among those who took part in the student survey. ${ }^{55}$ It is nonetheless troubling to note that, in 2009 when teachers were asked to name up to three resources which they had found to be, "particularly useful or effective in teaching about the Holocaust", Schindler's List was the single most frequently named resource among teachers of Key Stage 3 history. Twice as many teachers named this 
film as made reference to any textbook, for example. And among the 634 responses given to the question, a total of 140 referred to feature films or fictional television programmes including, The Pianist, The Boy in the Striped Pyjamas and an episode of the mini-series Band of Brothers. In comparison, 62 entries referred to documentaries. In interview, a number of teachers purposefully drew attention to the impact that the increasingly widespread availability of such films had had on their teaching approach. For example:

And I know that you shouldn't bring Hollywood films in ... You know, you've got to be aware that there are limitations to all this, but at the end of the day they're doing a far better visual job than I could ever do. Because they can't really read the sources - they can't read the sources properly. [But] they can watch that and they get it.

$[\ldots]$

I think that's maybe an important point in your research. I don't know - it has really changed teaching the Holocaust [. . . ] you have these modern day films that the kids can relate to.

Elsewhere in interview, some teachers made judgements about the relative educational value of certain films over others and commentators such Judith Doneson, for example, have critically explored the potentially judicious use of film in classroom contexts. ${ }^{56}$ However, what I consider especially salient in the extract from interview immediately above is the rationale this history teacher provides. She explains that film can do a "far better visual job" than she ever could in helping her students to "get it" and that this is important because her students "struggle" with historical sources - "they can't read [them] properly". In addition, these "modern day films" are produced in a manner that her students "can relate to" and this, for her and for many other teachers who took part in the study, is in itself a pedagogical priority. In essence, this is a rationale made of the basis of "accessibility" and of "relevance", both terms which we 
have already noted became policy buzzwords under the previous Labour government (in power from 1997 until 2010).

It would again be disingenuous to deny effective classroom pedagogy inevitably demands that teachers support their students in accessing curriculum content in various ways and in such a manner that they engage - or make things appear "relevant to" students' prior experience and everyday lives. However, it is also important to critically consider whether - and in what manner - notions of "accessibility" and/or "relevance" might be elevated such that they can in fact themselves serve to prohibit complex understanding and - in this case - obscure accurate historical detail. ${ }^{57}$ Indeed, this is precisely the sort of argument that motivated both Young and Wheelahan's knowledge re-centring interventions within educational theory.

By way of further illustration, in another interview a group of teachers explained that the definition of the Holocaust they offered their students was very consciously influenced by a concern to emphasise the subject's "relevance":

Teacher A: One of the ways that you can make it relevant to the pupils, because we're in a multiracial school, is the fact that anybody who is of a different race, who is not of the "Aryan" race, would not be living here if the Nazis had actually won the war.

Teacher B: I think that's really relevant in a school like this, isn't it - where we've got such a high number of Asian kids.

Teacher C: $\quad$ Yes, so we try and look at in a much broader way than just the Jews.

In a second school, another teacher explained:

But then I would mention other groups. Because my impression is the students get very sort of interested when you're having to mention physically and mentally handicapped people. ... And so they fall under this Holocaust umbrella. 
[ ... T The students that we teach aren't very familiar with Jewish people or whatever, but they may be more aware of physically and mentally handicapped people.

Again, while there may be many circumstances in which either "accessibility" or "relevance" constitute very sound educational principles, it is hard not to consider these two illustrations in light of the charge of instrumentalising the past. Here "relevance" is significantly impacting the manner in which "the Holocaust" is being presented to school students and, potentially, profoundly influencing their understanding of this history.

In the space remaining, it would be neither possible nor appropriate to attempt to adequately capture existing scholarly debate regarding exactly how the Holocaust should be defined. However, it is important to consider that, among academic historians, a majority reflect "the traditional view" that, although multiple groups were targeted in various ways under the Nazi regime, "the Holocaust" "was the genocide of the Jews alone". ${ }^{58}$ This distinction is also reflected in the definitions provided within both the Imperial War Museum's permanent Holocaust Exhibition and by the United Kingdom's Holocaust Memorial Day Trust. ${ }^{59}$ However, the most popular definition chosen by teachers in response to a related question in the 2009 survey referred to, "the persecution and murder of a range of victims" and did not denote the specificity of the experience of European Jews. ${ }^{60}$

It remains to be seen whether a change in national government with a significantly revised educational agenda and a professed commitment "to ensure that the acquisition of knowledge within rigorous subject disciplines is properly valued and cherished", ${ }^{61}$ will ultimately be successful in its attempts to eradicate a language of "access" and of "relevance" as teaching priorities. It is nonetheless interesting to reflect upon related findings from the more recent, student-focused, study as these appear to 
offer strong indication that teachers" concerns to "broaden", or "open out", the "umbrella" of the Holocaust have clear implication for student understanding of this history.

Students' conceptions of victimhood in relation to the Holocaust are examined in considerable detail within the full research-report publication, What Do Students Know and Understand About the Holocaust? However, a short discussion and summary of some of the report's key findings are salient to consider here. A clear majority of students across all age groups identified Jews as victims of the Holocaust. Indeed, in analysis of students' most immediate associations when asked simply to "describe" the Holocaust, "Jews", "Jewish people" or some other referent for "Jewishness" was the single most commonly referenced term. ${ }^{62}$ However, when asked directly within the survey, "Who were the victims of the Holocaust?", with age - and thus, broadly, with increased curricular exposure to the subject - students became more and more likely also to include other, non-Jewish, victims of Nazi persecution. Homosexuals, followed by disabled people and Roma and Sinti were the groups most likely to be included within students' answers here.

In interview too, students regularly emphasised, 'It was certainly more than just the Jews...'

Daniel: $\quad \ldots$ it was more ideas that Hitler had for . . a perfect . .

Sarah: [It was] people Hitler didn’t like

$[\ldots]$

Tom: $\quad$ Er, Jehovah's Witnesses, erm, disabled people, homosexuals, erm . .

Sarah: - basically anyone he didn’t like.

Tom: $\quad$ Yeah

Daniel: $\quad$. blue eyed, blonde hair.

Tom: $\quad$ People who didn't fit his ideology of the perfect Aryan race. ${ }^{63}$ 
It was anyone that was different, so like physical deformity, or gay, or anything like that, anyone who wasn't the 'ideal' person, basically, or what they considered the ideal person. ${ }^{64}$

The extracts above are illustrative of typical student responses: reference was regularly made to victims' perceived deviation from a "blonde hair, blue eyed" "norm" and a generalised, and often all encompassing, notion of "difference" - "anyone that was different from the Aryan race", "pretty much everyone apart from white Germans" could be targeted ${ }^{65}$ - was very often employed. In some instances, this logic led to entirely erroneous assumptions or inferences, for example the speculation that "Asians" and "Muslims" were also directly targeted by the Nazi regime:

I don't know if this is right but I think coloured people as well. Yeah, because I think, I don't know if this is right but I think he wanted everyone to be White. I don't know if that is true but yeah, and I think they were sent to the concentration camps as well along with Muslims. ${ }^{66}$

When asked to consider why specific, named groups of victims were targeted by the Nazis, most students really struggled to move beyond this most generalised notion of "difference". Their answers were commonly marked by significant uncertainty and ambiguity:

Interviewer: Why did he decide to target homosexuals for instance?

Courtney: Because he thought they were wrong.

Juliette: $\quad$ Yeah, they were different; he felt that they were the wrong species I guess.

Nina: Isn't it what Juliette said about them against Christianity?

Chloe: $\quad$ Yes, because somewhere in the bible it says that you have to marry the opposite gender, don't you - the opposite sex, yeah that is it. I think it was something about not going ahead with religious people. $^{67}$ 
Interviewer: Okay so Gypsies were another group who were targeted? What happened to Gypsies?

Holly: $\quad$ I don't really know about them that much

Imogen: $\quad$ Maybe - we do get taught that lots of people were involved were like victims of it but we mostly focus on the Jews and homosexuals sometimes. ${ }^{68}$

We haven't really done much about the disabled people and why he hated them, but I think it was - well we all think - that it was because they weren't able to fight for his country and that is all he wanted people for. ${ }^{69}$

In a similar manner, students also seemed almost entirely unfamiliar with the particular Nazi policies which were enacted against each different victim group. While some students made occasional reference to differential treatment of victims - "there were different sorts of degrees and levels of how badly they were treated"70 - this was almost always posited as a function of whether or not an individual was considered "useful" - or "usable". And so, for example, some students argued:

Like if they could work, like if they could slave or serve people, like maybe make artillery and that, then they would probably not be killed. But if like they couldn't work or they are too small or if they were like unusable in a way then they would probably be put to death either in the gas chamber or shot alive. ${ }^{71}$

Beyond differentiation related to "usability" on the basis of age and/or fitness, students overwhelmingly appeared to believe that all of the groups targeted by the Nazi regime faced a similar fate:

they did treat people the same way in the sense that if you weren't the way he wanted you to be, he was going to kill you. So in some ways they were all treated as an equal group. ${ }^{72}$ 
Weren't they all treated the same in concentration camps? Because to the Germans they are all minority enemies, so I'm not sure but I think, I'm not particularly sure that they were segregated and separated in the camps, I think they were all just systematically murdered in any way, shape of form. ${ }^{73}$

The work camps were built, I believe, before the Final Solution, and then the death camps were built after, so when you've got all these different groups being executed and killed I think most of them were lumped in with the Jews, because I agree with what Sam is saying about how Hitler targets the Jewish race specifically in his ideology and all the rest, as Mike said, the political prisoners, Slavs, Russians, and everyone else, ended up with the same fate because really it was convenient . . . basically everyone else found themselves suffering the same fate as the Jews because that was the fate that the Nazis marked out for them. ${ }^{74}$

Arguably, precisely what the majority of students who took part in the 2016 study appear to missing is "powerful" - accurate, nuanced - "knowledge" of Nazi policy and of the experience of these differently targeted victim groups. As such, their ability to understand the Holocaust itself - to begin to account for how and why it happened - let alone be able to abstract any meaningful generalisations - is significantly undermined. There is an important educational argument that it is not sufficient, nor instructive, to understand the Holocaust by collapsing the experiences of all victims of Nazi persecution into one homogenous group. Rather, young people could - and arguably should - be given opportunities to recognise that political opponents, gay men, Jehovah's witnesses, people with disabilities, black people and the Roma and Sinti, for example, were each identified as a threat to the Nazi regime at different stages, for very different reasons and therefore targeted in different ways and, critically, that only Jews were targeted for a European-wide genocide. Without at least some recognition of this complexity, students are left with the arguably somewhat "powerless" inference that some generalised and largely inexplicable fear and/or intolerance of "difference" was ultimately to blame. In this way an opportunity for students to confront and attempt to 
better understand the complex interplay and interdependence of eugenicist racial theory, populist nationalism, the mobilisation of centuries old antisemitism and, for that matter, political expedience - in both the past and, potentially, the present - is lost or denied.

It is in this regard that there can be a very significant tension between "powerful knowledge" - here derived through accurate historical detail - and the most generalist and universalising (or "pre-empting"), widely popular teaching aims. Let us consider for a moment the following teacher's articulation of why they felt it was so important to teach about the Holocaust in schools:

You know, knowledge is power to change things. And if we equip them with that knowledge, of how things can slip very quickly from almost like a bullying incident and end up in genocide ... It starts with name calling and it ends with the Holocaust. It can happen again - what is to stop it unless humanity stops it? It's happened before, and that's one of the things that worries me. And even now people are dying because of who they are, the colour of their skin, their religion. They are dying because of it and that's something we've got to continue to work to end. And the way we can do that is through knowledge and understanding of events like the Holocaust.

This teacher also clearly believes that there is an important link between knowledge and power and positions her educational purpose in this way. But can knowledge of the Holocaust ever really be understood to be "powerful" (in Young's sense of the term) if it fails to adequately account for the many times throughout history that "bullying" or "name calling" have not led to extreme, state-sponsored murder, or if it detracts from the very specific social, economic and political context within which this particular genocide was able to unfold? For this appears to be precisely the danger where the primary motivation for teaching about the Holocaust is to encourage students to take a stand against any form of identity-based prejudice or discrimination, in any place at any time. 
This is by no means to argue there are no civic, social or moral "lessons" from the Holocaust that, if not to be "learned" could nonetheless be instructively explored. In a 1999 article on antiracist education, Geoffrey Short urges teachers to facilitate students' critical engagement with the extensive historical and social scientific literature which has examined the actions and behaviours of those who perpetrated, collaborated, or might otherwise be seen to be held in some way responsible for the Holocaust such as Christopher Browning's examination of the choices made by the "ordinary men" carrying out orders as members of Police Battalion $101 .{ }^{75}$ Results from the 2016 student study suggest that this is an area of educational enquiry that continues to be largely unexplored. One question included within the survey asked students to consider, "If a member of the military or police refused an instruction to kill Jewish people, what do you think would be the most likely to happen to them?" As Browning and other leading academic historians have documented, the historical record suggests the most likely consequence was an excusal and reassignment to another duty: although it was explored as a possible line of defence during the Nuremberg trials, no documentary evidence has ever been found to suggest that any German soldier was ever shot or exiled to a concentration camp for refusing to obey such an order.

[Please insert 'Figure 2: 'If a member of the military or police refused an instruction to kill Jewish people, what do you think would be the most likely to happen to them? Student responses by year group here]

However, as Figure 2, illustrates, this scholarship appeared to have very little influence upon student understanding. Instead a clear majority of students across all year groups believed - or assumed - that dissenting officers would have been killed. Only a very small minority identified the most historically accurate answer. 
Indeed, and as reported throughout the 2016 study, students' answers to the question "Who was responsible for the Holocaust?" were very regularly limited to "Hitler" or, at best, "Hitler and the Nazis". The actions of other groups and individuals who might otherwise be considered complicit were invariably explained by students with reference to mitigating factors such as "fear", "ignorance" or "brain-washing". Again, accurate historical knowledge content could have a very powerful role to play here in providing an opportunity to interrupt, disturb and challenge students" "commonsense" understandings of human behaviour: for it is not only ideological despots, duped or fearful collaborators or ignorant bystanders who are capable of contributing to genocide. If education about the Holocaust is to realise its "subjectifying" potential, it is important that students are empowered - through expanded secure knowledge content to confront critical broader issues of individual and societal responsibility.

\section{Concluding reflections: The 'concept' and the content of the Holocaust - "socialising" or "subjectifying roles?}

To return to the original framing of this paper, in all of these illustrations the "details of the actual event", as student John put it, are in fact profoundly important: without them, "the concept" of the Holocaust - that is, the broader, abstracted meaning or "lesson" students are able to derive from their engagement with this history - is somewhat limited. However, for the purposes of educational "socialisation" or the inculcation of students into today's ostensibly shared societal "values", simply knowing that the Holocaust happened and "know[ing] that it's wrong" would probably suffice.

Indeed, and to paraphrase Benedict Anderson's famous term, there is an argument to make that, at the level of national government, where teaching and learning about the Holocaust is concerned, Michael Gove's insistence upon "the acquisition of knowledge within rigorous subject disciplines" is itself a lower-order priority than the 
socialisation of students into an imagined contemporary British community. ${ }^{76}$ In this regard, the following extract from the final report of the Prime Minister's Holocaust Commission is significant:

Ensuring that the memory and the lessons of the Holocaust are never forgotten lies at the heart of Britain's values as a nation. In commemorating the Holocaust, Britain remembers the way it proudly stood up to Hitler and provided a home to tens of thousands of survivors and refugees, including almost 10,000 children who came on the Kindertransports. In debating the more challenging elements of Britain's history - such as the refusal to accept more refugees or the questions over whether more could have been done to disrupt the Final Solution - Britain reflects on its responsibilities in the world today. In educating young people about the Holocaust, Britain reaffirms its commitment to stand up against prejudice and hatred in all its forms. The prize is empathetic citizens with tolerance for the beliefs and cultures of others. But eternal vigilance is needed to instil this in every generation. ${ }^{77}$

It is instructive to counter pose the Prime Minister's Holocaust Commission's official position here - with its emphasis on education to "instil tolerance" conceived as a British national value - with a somewhat alternative articulation of potential "lessons from the Holocaust" articulated by Henry Friedlander, the survivor and historian of the Holocaust already cited by Totten, Feinberg and Ferenkes above:

A final reason why we should teach the Holocaust is that its lessons can help us teach civic virtue. Purists may frown on this practice, but to a large degree this has always been part of education. Of course, I do not mean that the Holocaust should simply be used to teach conventional patriotism and accepted moral values; instead, its lessons must be used to demonstrate the need for what the Germans have called Zivilcourage. We need to teach the importance of responsible citizenship and mature iconoclasm. We must show how the only defence against persecution and extermination is citizens prepared to oppose the power of the state and to face the hostility of their neighbors to aid the intended victims. ${ }^{78}$ 
For as Friedlander highlights, there is a profoundly important distinction to make between "teaching conventional patriotism and accepted moral values" - which one could argue is reflected in much current educational policy and practice and which tends to operate primarily within the realm of educational socialisation - and the promotion of "Zivilcourage" or "mature iconoclasm" which depends upon students developing their own capacity for autonomous thought and action and which can only really be achieved when educational encounters are approached through Biesta's “subjectifying” educational lens.

The central argument presented within this paper, and made on the basis of empirical research with both teachers and students, is that for schools to provide specifically educational encounters with the Holocaust they need to ensure that they do more than simply reproduce or reinforce the (mis)understandings and "common sense" assumptions that many, if not most, of their students are likely already to have acquired. The paper has also argued it is unhelpful to reduce our conception of the possibilities of "moral" and/or "social" education to "moralising" and/or "social-engineering" and has resisted the reductionist and misleading discursive framework which so regularly positions unalloyed "historical" approaches in sceptical opposition to other, potentially "present-oriented" educational aims. Following Young and others, it argues instead that if education is to perform a potentially transformatory function - in any subject discipline - then it must provide students with access to "more reliable explanations", which may in turn fundamentally challenge or confound existing assumptions, as a basis to explore "new ways of thinking about the world" ${ }^{79}$ Such explanations must be built on secure and corroborated, appropriately detailed, "powerful knowledge", rooted in, but by no means necessarily restricted to, specialist historical scholarship. It is from this perspective that "the details of the actual event" - the specific reasons for distinct victim 
groups' targeting by the Nazis, as discussed above, for example, or the complexity of individual and group psychology, social relations and contingent power structures which led "ordinary" men and women to become complicit in a continental genocide are in fact key.

\section{References}

Barrow, R. “'Or what's a heaven for?' The importance of aims in education.” In The Aims of Education, edited by R. Marples, 14-22. London: Routledge, 1999. Beck, J. "Powerful Knowledge, Esoteric Knowledge, Curriculum Knowledge." Cambridge Journal of Education, 43, No. 2 (2013): 177-193.

Beck, J. “Reinstating Knowledge: Diagnoses and Prescriptions for England's Curriculum Ills" International Studies in Sociology of Education 22, No. 1 pp 118.

Barrett, B. and Rata, E. Knowledge and the Future of the Curriculum. Basingstoke: Palgrave Macmillan, 2014.

Biesta, G. Good Education in an Age of Measurement. Boulder: Paradigm, 2010.

Billingham, L. "Investigating Contingency in School History: An Aid to Rich, Meaningfully Critical Citizenship?, The Curriculum Journal (2016) doi:10.1080/09585176.2016.1143379

Brown, M. and Davies, I. "The Holocaust and Education for Citizenship: The Teaching of History, Religion and Human Rights in England" Educational Review, 50, No.1 (1998): 75-83.

Burtonwood, N., "Holocaust Memorial Day in Schools - Context, Process and Content: A Review of Research into Holocaust Education." Educational Research, 44, no.1 (2002): 69-82.

Cabinet Office. Britain's Promise to Remember: The Prime Minister's Holocaust Commission Report. London: Cabinet Office, 2015.

Carrington, B. and Short, G. "Holocaust Education, Anti-racism and Citizenship" Educational Review, 49, No.3 (1997): 271-82. 
Cowan, P. and Maitles, H. Cowan, P. and Maitles, H. 'Does Addressing Prejudice and Discrimination Through Holocaust Education Produce Better Citizens?" Educational Review, 59, No.2 (2007):115-30.

Counsell, C. "Disciplinary Knowledge for All, The Secondary History Curriculum and History Teachers’ Achievement.” The Curriculum Journal 22, No. 2 (2011): 201-225.

Counsell, C. and Kinloch, N. "Editorial”. Teaching History 104 (2001):2.

Davies, I. "Citizenship and the Teaching and Learning of History," In Issues in History Teaching edited by J. Arthur and R. Phillips, 137-147, London: Routledge, 2000.

Department for Education. The National Curriculum in Education: Key Stages 3 and 4 Framework Document. Department for Education, 2013.

https://www.gov.uk/government/uploads/system/uploads/attachment_data/file/2 39075/SECONDARY_national_curriculum_-_History.pdf

Doneson, J. "Why Film?” In Lessons and Legacies II: Teaching the Holocaust in a Changing World. 140-58, Evanston: Northwest University Press, 1998.

Evans, R. W. "Educational Ideologies and the Teaching of History." In Teaching and Learning in History, edited by G. Leinhardt, I. L. Beck and C. Stainton, 171208. Hove: Erlbaum, 1994.

Feinberg, S. "Studying and Teaching the Holocaust: A Journey". In Working to Make a Difference. The Personal and Pedagogical Stories of Holocaust Educators Across the Globe, edited by S. Totten, 31-50. Lanham: Lexington, 2003

Feinberg, S. and Totten, S. "Foundational Concerns: Developing Historically Accurate and Pedagogically Sound Holocaust Lessons and Units." In Essentials of Holocaust Education. Fundamental Issues and Approaches, edited by S. Totten and S. Feinberg, 1-17, New York: Routledge, 2016.

Foster, S., Pettigrew, A., Pearce, A., Hale, R., Burgess, A., Salmons, P., Lenga, R.A. What Do Students Know and Understand About the Holocaust? Evidence from English Secondary Schools. London: Centre for Holocaust Education, 2016.

Friedlander, H. "Toward a Methodology of Teaching about the Holocaust." Teachers College Record 80, no. 3, (1979): 519-542.

Gewirtz, S. The Managerial School: Post-Welfarism and Social Justice in Education. London: Routledge, 2002. 
Gove, M. What is Education For? Speech by Michael Gove to the Royal Society of Arts. 2009. www.michaelgove.com

Hammond, K. "From Horror to History: Teaching Pupils to Reflect on Significance", Teaching History, 104 (2001): 15-23.

Harris, R. and Burn, K. "Curriculum Theory, Curriculum Policy and the Problem of IllDisciplined Thinking.” Journal of Education Policy, 26, No 2 (2011):245-261.

Haste, H. "Citizenship Education: A Critical Look at a Contested Field." In Handbook of Research on Civic Engagement in Youth edited by L. R. Sherrod, J. TorneyPurta and C.A. Flanagan. Hoboken: John Wiley \& Sons, 2010

Haydn, T. "Teaching the Holocaust through History" In Teaching the Holocaust:

Educational Dimensions, Principles and Practice, edited by I. Davies, 135-150. London: Continuum, 2000.

Hawkey, K. "Mediating Narrative in Classroom History." International Journal of History Learning, Teaching and Research, 6, No. 1 (2006): 1-10.

Illingworth, S. 'Hearts, Minds and Souls: Exploring values Through History". Teaching History 100 (2000): 22.

International Holocaust Remembrance Alliance (IHRA). "Why Teach About the Holocaust?”. International Holocaust Remembrance Alliance. Accessed April 2, 2016. https://www.holocaustremembrance.com/node/315

Kitson, A. "Challenging stereotypes and avoiding the superficial:a suggested approach to teaching the Holocaust" Teaching History, 104 (2001): 41-48.

Kinloch, N. "Learning about the Holocaust: moral or historical question?” Teaching History, 93 (1998): 44-6.

Langer, L. Preempting the Holocaust. London: Yale University Press, 1998.

Lee, P. “Why learn history?” In Learning history, edited by In A. Dickinson, P. Lee and P. Rogers, London: Heinemann, 1984.

Lee, P. "Historical knowledge and the National Curriculum". In History in the National Curriculum, edited by R. Aldrich. London: Kogan Page, 1991.

Lee, P., Shemilt, D., Slater, J., Walsh, P., and White, J.,The aims of school history: The National Curriculum and beyond. London: the Tufnell Press, 1992.

Meagher, M. "Letter.” Teaching History 94, (1999): 3.

Niewyk, D. and Nicosia, F. The Columbia Guide to the Holocaust. New York: Columbia University Press, 2000. 
Ormond, B. "Powerful Knowledge in History: Disciplinary Strength or Weakened Episteme?" In Knowledge and the Future of the Curriculum, edited by B. Barrett and E. Rata, 153-166. Basingstoke: Palgrave Macmillan, 2014.

Parsons, W. and Totten, S. "Guidelines for Teaching About the Holocaust." United States Holocaust Memorial Museum, 1993. https://fcit.usf.edu/holocaust/sites/USHMM/guideint.htm

Pearce, A. Holocaust Consciousness in Contemporary Britain. London: Routledge, 2014.

Pettigrew, A. Foster, S., Howson, J., Salmons, P., Lenga, R-A., Andrews, K. Teaching About the Holocaust in English Secondary Schools: An empirical study of national trends, perspectives and practice. London: Holocaust Education Development Programme, 2009.

Pring, R. "Neglected Educational Aims: Moral Seriousness and Social Commitment. In The Aims of Education, edited by R. Marples, 157-172. London: Routledge, 1999.

Qualifications and Curriculum Authority, Education for Citizenship and the Teaching of Democracy in schools: Final report of the Advisory Group on Citizenship (Crick Report). London: Qualifications and Curriculum Authority and Department for Education and Employment.

Rata, E. and Barrett, B. "Introduction: Knowledge and the Future of the Curriculum." In Knowledge and the Future of the Curriculum, edited by B. Barrett and E. Rata, 1-20. Basingstoke: Palgrave Macmillan, 2014.

Russell, L. Teaching the Holocaust in School History: Teachers Or Preachers. London: Continuum, 2006.

Salmons, P. "Teaching or Preaching? The Holocaust and Intercultural Education in the UK” Intercultural Education 14, no. 2 (2003): 139-149.

Salmons, P “Universal Meaning or Historical Understanding” Teaching History 141 (2010): 58- 63.

Short, G. "Lessons of the Holocaust: A Response to the Critics." Educational Review 55, no. 3 (2003): 277-287.

Short, G. "Antiracist Education and Moral Behaviour: Lessons from the Holocaust" Journal of Moral Education. 28, No.1 (1999): 49-62 
Standish, P. "The Nature and Purposes of Education." In A Companion to the Philosophy of Education, edited by R. Curren, 221-231. Oxford: Blackwell, 2003.

Tosh, J. Why history matters. Basingstoke: Palgrave Macmillan, 2008

Totten, S., Feinberg, S. and Fernekes, W. "The Significance of Rationale Statements in Developing a Sound Holocaust Education Program.” In Teaching and Studying the Holocaust edited by S. Totten and S. Feinberg, Boston: Allyn and Bacon, 2001.

Wheelahan, L. "How Competency-based Training Locks the Working Class Out of Powerful Knowledge: A Modified Bernsteinian Perspective.” British Journal of Sociology of Education 28, No.5 (2007): 637-51.

White, J. Education and the Good Life: Autonomy, Altruism, and the National Curriculum. New York: Teachers College Press, 1991.

Wringe, C. Moral Education: Beyond the Teaching of Right and Wrong. Dordrecht: Springer, 2006.

Young, M. "Knowledge, Curriculum and the Future School." In Knowledge and the Future School, edited by M. Young and D. Lambert, 9-40. London: Bloomsbury, 2014.

Young, M. "Overcoming the Crisis in Curriculum Theory: A Knowledge-Based Approach.” Journal of Curriculum Studies 45, No. 2 (2013):101-118.

Young, M. "The Return to Subjects: A Sociological Perspective on the UK Coalition Government's Approach to the 14-19 Curriculum” The Curriculum Journal 22 No. 2, (2011) 265-278

Young, M. "What Are Schools For?” Educação, Sociedade and Culturas, No. 32, (2011): 145-155

Young, M. "The Future of Education in a Knowledge Society: The Radical Case for a Subject-Based Curriculum" Journal of the Pacific Circle Consortium for Education 22, No. 1 (2010) 21-32.

Young, M. "From Constructivism to Realism in the Sociology of the Curriculum." Review of Research in Education 32 (2008):1-32

Young, M. and Muller, J. "Three Educational Scenarios for the Future: Lessons from the Sociology of Knowledge" European Journal of Education 45, No. 1 (2010) $11-27$ 
1. Secondary school history teacher cited in Pettigrew et al., Teaching About the Holocaust, 81.

2. Interview with Year 12 secondary school students cited in Foster et al, What Do students Know?, 85.

3. The term "symbolic significance" is used purposefully here because in recent years, the functional power of a single national curriculum has been weakened considerably as schools have been encouraged by government to adopt "academy" or "free school" status, both of which give individual institutions far greater autonomy in determining their curricula and educational priorities.

4. DfE, The National Curriculum, 4.

5. The English education system is structured as a series of 'Key Stages'. 'Key Stage 3' denotes the first three years of secondary schooling - Years 7, 8 and 9, in which students are typically aged between 11 and 14 .

6. DfE, The National Curriculum, 4.

7. Pearce, Holocaust Consciousness in Britain; Russell, Teaching the Holocaust.

8. Throughout this paper, pseudonyms have been used for all students whose interview contributions are cited while teachers are identified instead as, for example, "Teacher A" or "Teacher B". This is consistent with the original research studies from which these extracts are drawn.

9. Pettigrew et al., Teaching About the Holocaust, and Foster et al., What do Students Know?

10. Biesta, Good Education.

11. See for example, Young, "Knowledge Curriculum and the Future School"; Young and Muller, "Three Educational Scenarios"; Wheelahan, "Competency-Based Training".

12. Parsons and Totten, "Guidelines for Teaching."

13. IHRA "Why Teach About the Holocaust?"

14. See, for example, Moisan, Hirsch and Audet's Canadian study, Kühner, Langer and Sigel's research with teachers in Germany, Ambrosewicz-Jacobs and Büttner (Poland), Wibaeus (Sweden) and Cohen (Israel) all cited within Eckmann et al., Multi-Year Work Plan: Education Report.

15. Counsell and Kinloch "Editorial". 
16. Totten, Feinberg and Ferenkes, "The Significance of Rational Statements", 1. For a much more recent articulation of this same sentiment, see also Feinberg and Totten, "Foundational Concerns".

17. Totten, Feinberg and Ferenkes, "The Significance of Rational Statements", 2.

18. Kinloch, "Learning about the Holocaust", 46.

19. See, for example, Salmons “Teaching or Preaching”; Illingworth "Hearts, Minds and Souls"; Meagher "Letter"; Kinloch "Learning About the Holocaust"; Haydn "Teaching the Holocaust Through History"; Russell "Teaching the Holocaust"; For a different entry-point into related debates see also, Brown and Davies "The Holocaust and Education for Citizenship"; Carrington and Short "Holocaust Education, Antiracism and Citizenship"; Cowan and Maitles, "Addressing Prejudice and Discrimination".

20. See also Kitson, A."Challenging stereotypes" and Hammond, K. "From Horror to History"..

21. Kinloch, "Learning about the Holocaust", 45; Russell, Teaching the Holocaust, 34.

22. See, for example Lee, "Why Learn History?”, "Historical Knowledge”; Lee et al. Aims of School History; Tosh, Why History Matters; Harris and Burn, “Curriculum Theory, Curriculum Policy"; Counsell, "Disciplinary Knowledge for All"; Ormond, "Powerful Knowledge in History".

23. In 2009, among 1,085 teachers who told us in which subject their teaching about the Holocaust principally took place, $55 \%$ reported that they principally taught about the Holocaust within history classes, $25 \%$ within religious education, $7 \%$ within English and 3\% within both citizenship and PSHE, Pettigrew et al. Teaching About the Holocaust, 34. Within the 2016 student study, among those who had already learned about the Holocaust $(n=5,651) 86.1 \%$ had done so in history, $37.5 \%$ in religious education, $27.0 \%$ in English, $26.2 \%$ in school assemblies $10.7 \%$ in citizenship or PSHE and $5.9 \%$ in drama.

24. Many would, however, argue for the primacy of secure and accurate historical knowledge as the basis upon which other forms of understanding could be drawn. This is a salient point to which we will return.

25. Lee "The Holocaust in the National Curriculum, Tosh , "Why History Matters".

26. Hawkey, "Mediating Narrative", 6.

27. Burtonwood, N., "Holocaust Memorial Day in Schools"; Salmons, P. "Teaching or Preaching?", 140. 
28. Qualifications and Curriculum Authority, Education for Citizenship, 22; Davies, I., "Citizenship and History."

29. Kinloch, "Learning About the Holocaust"; Russell, Teaching the Holocaust;

Salmons, "Teaching or Preaching"; Pearce, Holocaust Consciousness.

30. See, for example, Wringe, Moral Education; Haste, “Citizenship Education”;

Billingham, "Investigating Contingency".

31. Kinloch, "Leaning About the Holocaust"; Russell, Teaching the Holocaust;

Salmons, "Teaching or Preaching".

32. Langer, Preempting the Holocaust, 1.

33. Salmons, "Teaching or Preaching”, 141.

34. Ibid.

35. Ibid, 142.

36. Ibid, 141, emphasis added.

37. Haydn, "Teaching the Holocaust Through History", 137

38. See for example, Pring, "Neglected Aims" and Billingham, "Investigating Contingency".

39. White, Education and The Good Life, 10. See also, Barrow, “Or What's a Heaven For?" Standish, "The Nature and Purposes of Education".

40. See also, Standish, "The Nature and Purposes of Education” and Gewirtz, The Managerial School.

41. Biesta Good Education, 4. Emphasis added.

42. Parsons and Totten, Guidelines for Teaching, 1.; IHRA Why Teach about the Holocaust?, emphasis added.

43. Ibid 19-22.

44. Ibid, 22.

45. See, for example various contributors to Barrett and Rata, Knowledge and the Future of the Curriculum.

46. Although not exactly equivalent to the earlier question, "What is education for", "What are schools for?" is the question Young himself used to frame a 2011 article of the same name.

47. Young, "Knowledge, Curriculum, Future School”, 11.

48. Ibid, 10.

49. Young, "The Future of Education", 21. 
50. See, for example, Young and Muller, “Three Scenarios" Young and Lambert, Knowledge and the Future School.

51. Young, "From Constructivism to Realism", 14. See also, Wheelahan.

52. Harris and Burn, "Curriculum Theory, Curriculum Policy”; Counsell, "Disciplinary Knowledge for All"; Ormond, "Powerful Knowledge in History".

53. Cole, Selling the Holocaust, 3.

54. Ibid., 75-6.

55. Foster et al., What Do Students Know? See also Gray, “A Blessing or Curse?”

56. Doneson, "Why Film?”; Baron, "Incorporating Film".

57 Harris and Burn "Curriculum Theory, Curriculum Policy" and Ormond, "Powerful Knowledge in History.

58 Niewyk and Nicosia, The Columbia Guide 51.

59 For a fuller discussion see Foster, et al. What Do Students Know? 9.

60 See Pettigrew, et al Teaching and Learning, 71-80. Teachers completing the survey were presented with a list of 7 possible definitions for the Holocaust and invited to choose the one that most closely reflected their own understanding of the Holocaust. In total $52.5 \%$ of all teachers surveyed (and $52.9 \%$ of all history teachers) chose this inclusive definition. The next most popular option was only chosen by $24.8 \%$.

61 Gove, What is Education For?

62 Foster et al. What Do Students Know? 42.

63 Extract from interview with Year 10 students, previously unreported.

64 Extract from interview with 'Erin', Year 12.

65 Extracts from interview with 'Cassie', Year 13 'Ash', Year 9, (emphases added).

66 Extract from interview with Charlotte, Year 8.

67 Extract from interview with Year 9 students.

68 Extract from interview with Year 10 students.

69 Extract from interview with 'Juliette', Year 9.

70 ‘Tom', Year 10 student.

71 'Vic', Year 9 student.

72 'Sarah', Year 10 student. 
73 'Mike', Year 12 student.

74 'Simon', Year 13.

75 Short, "Antiracist Education".

76 For a related interpretation of conservative education policy see also Beck,

"Reinstating knowledge".

77 Cabinet Office, Britain's Promise to Remember, 9.

78 Friedlander, "Toward a Methodology", emphasis added.

79 Young, "From Constructivism to Realism”, 14. 